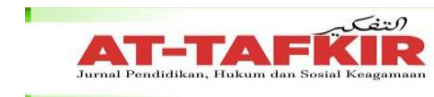

VOLUME 13 NOMOR 2 TAHUN 2020

P-ISSN : 1979-9357

E-ISSN : 2620-5858

\title{
Pemikiran Fikih Abuya Muhammad Wali Al-Khalidi (Analisis Kitab Al-Fatawa)
}

\author{
Safriadi \\ IAIN Lhokseumawe \\ safriadi@iainlhokseumawe.ac.id
}

\begin{abstract}
The Book of al-fatawa has a great contribution to the dynamics of development of Islamic law in this region of the Archipelago Islands. As for the complexion of his fikih thoughts nuanced bayāni-Tahlīlī. This research is descriptive-analysis with qualitative approaches. The results of this study revealed that Abuya Muhammad Waly al-Khalidi was a mujaddid (renewer) in the 14th-century hijrah, and a scholar was highly productive, during his lifetime preoccupied with scholarship activities with various disciplines, many of the wreaths he had made, which showed the breadth of science he had. One of his works in fikih is the book of al-Fatawa which is a collection of answers from questions sent by the community from various regions of Aceh as well as outside Aceh.
\end{abstract}

Keyword: Abuya Muhammad Wali, Al-Fatawa, Al-Khalidi, Fikif

\begin{abstract}
Abstrak: Kitab al-fatawa memiliki kontribusi yang besar dalam dinamika perkembangan hukum Islam di wilayah Kepulauan Nusantara ini. Adapun corak pemikiran fikihnya bernuansa bayāni-Tahlīlì. Penelitian ini bersifat analisis-deskriptif dengan pendekatan kualitatif. Hasil penelitian ini mengungkapkan bahwa Abuya Muhammad Waly al-Khalidi adalah mujaddid (pembaharu) pada abad ke-14 hijrah, dan seorang ulama sangat produktif, semasa hidupnya disibukkan dengan kegiatan keilmuan dengan berbagai disiplin ilmu, banyak karangan yang beliau buat, yang menunjukkan keluasan ilmu yang beliau miliki. Salah satu karyanya di bidang fikih adalah kitab al-Fatawa yang merupakan kumpulan jawaban dari pertanyaan-pertanyaan yang dikirimkan oleh masyarakat dari berbagai daerah di Aceh maupun luar Aceh.
\end{abstract}

Kata Kunci: Abuya Muhammad Wali, Al-Fatawa, Al-Khalidi, Fikif

\section{PENDAHULUAN}

Abuya Muhammad Wali (1917-1961 M) dikenal oleh masyarakat Aceh pada khususnya dan Indonesia pada umumnya adalah sebagai salah seorang Ulama besar yang berpengaruh terhadap masyarakat, dan juga beliau dikenal sebagai ilmuwan yang tekun mendalami berbagai bidang kajian keislaman antara lain ilmu fikih, kalam (tauhid), logika (mantiq), dan tasawuf. Karya-karyanya baik dalam ilmu kalam, fikih, dan tasawuf, pada umumnya bersifat deskripsi dengan pendekatan sosiologis. Karya-karya beliau memberikan sumbangan pemikiran terhadap pembaharuan hukum Islam di Aceh dan untuk mendukung terhadap tradisi yang sudah berkembang sebelumnya di Aceh, menurut analisis beliau bahwa tradisi tersebut tidak melanggar dengan ketentuan hukum Islam, bahkan harus dipertahankan.

Abuya Muhammad Wali sangat banyak melahirkan para Ulama yang kemudian tersebar ke seluruh pelosok daerah di Aceh dan di luar Aceh untuk mengembangkan syariat Islam kepada masyarakat. Gerakan dan kegiatan tersebut berhasil dilakukan oleh Abuya Muhammad Wali untuk merubah pola dan tata cara beragama masyarakat serta peningkatan kualitas dalam hal ibadah (hablumminallah), dan mua'amalah (hablumminannās). Disebutkan sebagai suatu gerakan, karena Abuya Muhammad Wali berhasil mengorganisir suatu potensi 


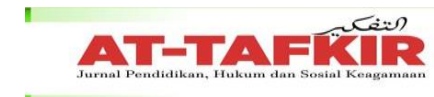

VOLUME 13 NOMOR 2 TAHUN 2020

P-ISSN : 1979-9357

E-ISSN : 2620-5858

besar yang menjadi faktor penentu perubahan hukum Islam. Gerakan itu dimulai dengan sangat sederhana dari mengajar dan menjawab pertanyaan terhadap permasalahan yang muncul di balee dengan ruang lingkup terbatas, kemudian berkembang menjadi gerakan pembaharuan. Atas dasar itu, Abuya Muhammad Wali sangat tepat disebut sebagai perancang, pemikir perubahan dan pembaharu dalam pengembangan hukum Islam di Aceh. Tampilnya sosok Abuya Muhammad Wali tidak terlepas dari sosio kultur akademis saat itu (Fikri).

Ada tiga hal utama yang selalu diingat oleh orang ketika nama Abuya Muhammad Wali disebutkan. (Pertama) peranannya dalam mengembangkan fikih Syafi'iyah, melahirkan para Ulama besar di Aceh, (kedua) sosok Ulama yang mendukung pemerintah dari rongrongan kelompok DI/TII dengan fatwafatwanya. (Ketiga) pengembangan intelektualnya ke Makkah (Zuhri, 2014). Akibat kegigihan dan perjuangannya dalam mengembangkan agama dan melahirkan Ulama besar di Aceh yang berpengaruh sampai dengan sekarang ini. Pada tanggal 07 Mei 2007, para Ulama yang ikut dalam forum tinggi Ulama Aceh di Mesjid Raya Baiturrahman yang merupakan mesjid kebanggaan masyarakat Aceh sepakat untuk memberi gelar kepada Abuya Muhammad Wali sebagai ulama 'Arifbillah.

Kiprah beliau terekam ketika mengawal kengonjang-ganjingan suasana masyarakat Aceh pada masa pemberontakan DI/TII, dengan fatwanya melarang masyarakat Aceh untuk ikut dalam pemberontakan itu karena dianggap sebagai bughah terhadap pemerintahan yang sah pada masa itu yang dipimpin oleh presiden Soekarno, bahkan ia yang memberikan gelar kepada presiden Soekarno dengan ulil amri dharuri bi al-syaukah dan usulan itu diterima secara aklamasi oleh semua ulama seluruh Indonesia yang hadir di Istana Cipanas pada tahun 1957.

Pemahaman fikih yang dibangun oleh Abuya Muhammad Wali memandang bahwa pendapat-pendapat fikih ulama masa lalu adalah relatif dan tidak kebal terhadap perkembangan sosial, oleh karena demikian beliau berpendapat pembaharuan terhadap pemikiran hukum Islam suatu keharusan, agar umat Islam mampu menjawab tantangan dan problema sosial yang muncul dikemudian hari. Tidak seperti pada umumnya yang beranggapan bahwa fikih indentik dengan hukum Islam dan hukum Islam indentik dengan aturan Allah, maka sebagai konsekwensinya adalah fikih tidak boleh untuk dirubah meskipun kondisi sosial berharap untuk dirubah. Salah satu kitab representatif tentang fikih yang ditulis oleh Abuya Muhammad Wali adalah kitab al-Fatawa. Oleh karena demikian, penulis ingin membedah lebih jauh tentang isi kita tersebut.

\section{Biografi Abuya Muhammad Wali al-Khalidi}

Abuya Muhammad Wali dilahirkan didesa Blang Pohroh, kecamatan Labuhan Haji, kabupaten Aceh Selatan, Aceh-Indonesia pada tahun 1338 H/1917 M (Waly M. , 1993). Tidak ada yang mengetahui dari keluarganya tentang hari dan tanggal apa ia dilahirkan. Fenomena ini merupakan hal yang sering terjadi tentang orang-orang tua kita zaman dahulu. Meskipun mereka seorang ulama, tetapi tentang mencatat hari dan tanggal kelahiran anak cucu kurang diperhatikan mereka hanya mengingat tahun kelahirannya saja. Beliau adalah putra bungsu dari putra-putri Syeikh Haji Muhammad Salim bin Malin Palito. Setelah beberapa lama

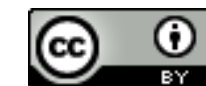

This work is licensed under a Creative Commons Attribution 4.0 International License 


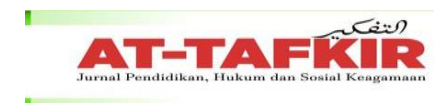

VOLUME 13 NOMOR 2 TAHUN 2020

P-ISSN : 1979-9357

E-ISSN : 2620-5858

Syeikh Haji Muhammad Salim bin Palito menetap di Labuhan Haji, ia dijodohkan dengan seorang wanita yang bernama Siti Janadat, putri seorang kepala desa kalau di Aceh sering orang menyebut dengan istilah Keuchik yang bernama Nya Ujud yang berasal dari Desa Kota Palak, Kecamatan Labuhan Haji, Aceh Selatan (Waly A., 2006).

Siti Janadat ibu kandungnya Abuya Muhammad Wali meninggal dunia ketika melahirkan adiknya dari Abuya Muhammad Wali (Abbas). Ibu Abuya Muhammad Wali meninggal bersama adik bayinya. Kondisi seperti ini Syaikh Muhammad Salim Palito sangat menyayangi Abuya Muhammad Wali melebihi saudaranya yang lain. Kemana saja ia pergi mengajar dan berdakwah Abuya Muhammad Wali selalu digendong oleh ayahnya. Adapun urutan isteri dan anak beliau adalah sebagai berikut:

a. Hj.Rasimah Istri beliau dari Sumatra Barat

Istri pertamanya bernama Hj. Rasimah, darinya dikaruniai keturunan, yaitu: Muhibbbuddin Wali, Halimah Wali, Muhammad Wali (beliau meninggal diwaktu kecil), Djamaluddin Wali, Nahyatuddin Wali (beliau meninggal diwaktu kecil), Marhaban Wali, Nurhayati Wali (meninggal diwaktu kecil), Ahmad Khatib Wali (meninggal diwaktu kecil), Muhammad Rum Wali (meninggal diwaktu kecil) dan Burhan Wali (meninggal waktu kecil), Ruslan Wali. Istri kedua bernama Hj. Siti Rabi'ah, darinya dikaruniai dua orang anak yaitu Ahmad Wali dan Mawardi Wali. Sedangkan istri ketiga bernama Umi Supayang. Darinya tidak dikaruniai anak.

b. Istri beliau dari Aceh

Istri keempat Abuya Muhammad wali bernama Hj. Riadhatunnur, darinya dikaruniai dua anak, yaitu Hj. Zubaidah Wali dan Amran Wali. Dan istri kelima adalah Piek Putieh. Darinya dikaruniai tiga orang anak yaitu Harun Wali, Muhammad Nasir Wali, dan Abidah Wali, dan istri yang terakhir adalah Umi Ainsyah, darinya memperoleh keturunan yaitu Mariah Wali dan Abdul Rauf Wali. Sebahagian besar anak beliau ini menjadi ulama besar serta mengikuti jejak perjuangan beliau, mengajar, berdakwah, dan memimpin pendidikan dan ritual peribadatan dengan mendirikan dayah dan sekolah agama baik di Aceh maupun di Sumatera Barat (Waly A. , 2006).

\section{Rihlah Intelektual}

a) Belajar pada orang tua

Abuya Muhammad Wali belajar cara membaca Alquran dan kitab-kitab kecil tentang tauhid, fiqh, dan dasar ilmu bahasa Arab pada ayahnya. Pembelajaran ini sering dilakukan pada malam hari sesudah shalat maghrib, sebagaimana lazimnya dilakukan oleh para masyarakat di Aceh tempo dulu dan sekarang.

b) Belajar di Dayah Jami'ah Al-Khairiyah

Setelah tamat sekolah Volks-School, beliau diajak untuk belajar oleh ayahnya ke sebuah Pesantren di ibu kota Labuhan Haji yaitu pesantren Jam `iah AlKhairiyah yang dipimpin oleh Teungku Muhammad Ali yang dikenal oleh

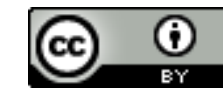

This work is licensed under a Creative Commons Attribution 4.0 International License 


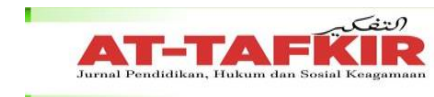

VOLUME 13 NOMOR 2 TAHUN 2020

P-ISSN : 1979-9357

E-ISSN : 2620-5858

masyarakat dengan panggilan Teungku Lampisang dari Aceh Besar. Kurang-lebih selama 4 tahun beliau belajar di pesantren Al-Khairiyah. Lalu kemudian beliau melanjutkan pendidikan pesantren Bustanul Huda di ibukota kecamatan Blangpidie. Atas dasar arahan, bimbingan dari ayahnya. Di pesantren Bustanul Huda, beliau mempelajari kitab-kitab yang masyhur dikalangan ulama Syafìiyah dalam bidang fikih seperti I ānah al-Talibīn, Tahrīr, dan Mahally, dalam ilmu nahwu dan ilmu saraf seperti Alfiyah dan Ibn 'Aqil. Setelah beberapa tahun lamanya di Pesantren Bustanul Huda, konflik terjadi antara beliau dengan gurunya yaitu Teungku Syeikh Mahmud, tentang perbedaan pendapat pada persoalan berzikir dan bershalawat sesudah shalat di dalam masjid secara jhar (mengeraskan suara).

Akibat dari perbedaan dalam permasalahan tersebut lalu Abuya Muhammad Wali ingin melanjutkan pendidikan kepesantren lainnya yang ada di Aceh Besar, namun sebelum beliau melanjutkan pendidikan ke pesantren lain terlebih dahulu ayahnya Haji Muhammad Salim meminta izin kepada Syekh Mahmud agar Abuya Muhammad Wali untuk dapat melanjutkan pendidikan ke pesantren lainnya serta memohon untuk dapat dimaafkan Abuya Muhammad Wali atas kelancangan terhadap gurunya pada perbedaan pendapat dalam masalah tersebut. meskipun Abuya Muhammad Wali berkali-kali dan ayahnya mohon untuk dimaafkan kepada Syeikh Mahmud namun sang gurunya tetap tidak memberikan jawaban apapun terhadapnya.

c) Belajar di Dayah Krueng Kalee

Setelah beberapa tahun belajar di Bustanul Huda pada tahun 1935 di usianya yang ke 18 tahun, ia melanjutkan pendidikannya ke pesantren Krueng Kalee di Aceh Besar (Waly M. , 1993).

d) Belajar di Dayah Indrapuri

Lamanya Abuya Muhammad Wali di Pesantren Kreung Kalee hanya tidak lebih satu hari, beliau bersama Tengku Salim mencari pesantren lain untuk menambah ilmu. Akhirnya merekapun berpisah. Kemudian Abuya Muhammad Wali mendapatkan informasi bahwa ada seorang ulama lain yang ada di Aceh Besar yaitu teungku Hasballah Indrapuri dimana beliau memiliki sebuah pesantren di Indrapuri. Pesantren yang beliau pimpin lebih menonjol dalam ilmu Al-Quran yang berkaitan dengan qira'ah dan lainnya. Belajar di Normal Islam School

Setelah sekian lamanya di Pesantren Indrapuri, datanglah tawaran dari salah seorang pemimpin masyarakat yaitu Teuku Hasan Glumpang Payung kepada Abuya Muhammad Wali untuk belajar ke sebuah perguruan di Padang yaitu Normal Islam School yang didirikan oleh seorang ulama jebolan dari universitas alAzhar kairo Mesir yaitu namanya Ustad Mahmud Yunus. Teuku Hasan setelah memperhatikan kepribadian Abuya Muhammad Wali, timbullah niat dalam hatinya bahwa pemuda ini perlu dikirim ke al-Azhar kairo mesir. namun karena di Sumatera Barat sudah terkenal ada seorang Ulama jebolan dari al Azhar dan Darul Ulum di kairo mesir yang bernama Ustad Mahmud Yunus yang telah mendirikan sebuah perguruan di Padang yang bernama Normal Islam School yang sudah terkenal kala itu melebihi perguruan-perguruan sebelumnya seperti Sumatera Thawalib. 


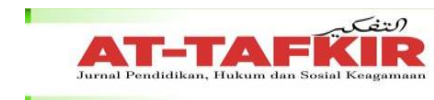

VOLUME 13 NOMOR 2 TAHUN 2020

P-ISSN : 1979-9357

E-ISSN : 2620-5858

Oleh sebab itu Teungku Hasan mengirimkan Abuya Muhammad Wali ke pesantren tersebut sebagai jenjang atau pendahuluan sebelum melanjutkan ke alAzhar. Setelah sampai di Normal Islam school beliau segera mendaftarkan diri di Sekolah tersebut.

\section{e) Belajar ke Arab Saudi (Makkah dan Madinah)}

Ketika Abuya Muhammad Wali masih di Padang, beliau sangat terkenal di sana dengan kealimannya sehingga banyak tokoh ulama di Padang yang berkenalan dengan Abuya Muhammad wali salah satunya adalah Syekh Khatib Ali. Ia sangat tertarik kepada Abuya Muhammad Wali sehingga beliau menjodohkan Abuya Muhammad Wali dengan seorang dari keluarganya yaitu $\mathrm{Hj}$. Rasimah. Sejak itulah kemasyhuran Abuya Muhammad Wali semakin meningkat dan terus dijadikan bahan pembicaraan para ulama-ulama besar lainnya dalam kelompok para kaum tua, tetapi beliau secara tidak langsung juga mengambil hal yang baik dari ulamaulama lainnya, seperti orang tuanya Buya Hamka, Haji Rasul. Kemudian Syekh Abuya Muhammad Wali juga berkenalan dengan Syekh Muhammad Jamil Jaho. Lalu beliau mengikuti pengajian yang diisi oleh Ulama besar Padang tersebut. Hubungan beliau dengan Abuya Muhammad Wali pada mulanya hanya sekadar guru dan murid.

Syekh Jamil Jaho adalah seorang ulama besar diminangkabau, muridnya Syekh Ahmad Khatib. Beliau diakui kealimannya oleh ulama lainnya terutama dalam ilmu bahasa Arab. Di Pesantren jaho itulah Syekh Muhammad Jamil Jaho mengumpulkan murid-muridnya yang pintar untuk menguji pengetahuan Syekh Abuya Muhammad Wali tradisi waktu itu, prosesnya mereka seperti mengaji seperti biasa pada Abuya Muhammad Wali tapi pada hakikatnya adalah untuk menguji Abuya Muhammad Wali dengan berbagai ilmu pengetahuan yang dimilikinya. Hasilnya semua perdebatan yang terjadi ketika itu dapat dijawab oleh Abuya Muhammad Wali dengan izin allah. Dari situlah, Abuya Muhammad Wali semakin terkenal dikalangan para ulama Minangkabau. Kemudian Abuya Muhammad Wali dinikahkan dengan putri Syekh Muhammad Jamil Jaho yaitu dengan seorang putrinya yang juga alim, Hajjah Rabi ah yang akhirnya melahirkan Syekh H.Mawardi Waly. Akhirnya Abuya Muhammad Wali menempati rumah pemberian paman istri beliau yang pertama, Hajjah Rasimah (Waly M. , 1993).

Pada tahun 1939 M, Abuya Muhammad Wali menunaikan ibadah haji ketanah suci bersama salah seorang isteri beliau Hajjah Rabiah. Selama di Mekkah, selain menunaikan ibadah haji, beliau juga memanfaatkan waktu untuk menimba ilmu pengetahuan dari ulama-ulama yang mengajar di Masjidil Haram antara lain Syekh Ali al-Maliki. Ketika Syekh Abuya Muhammad Wali berada di Madinah, ia berdiskusi dengan para ulama-ulama dari negeri lain terutama dari Mesir. Beliau tertarik dengan dengan perkembangan ilmu pengetahuan di negeri Mesir, sehingga ia sudah merencanakan untuk pergi ke Mesir, tetapi beliau lupa bahwa pada saat itu bahwa ia membawa istrinya Hajjah Rabiah. Istri beliau keberatan bila ditinggalkan dan lalu pulang ke Indonesia. Akhirnya beliau tidak jadi berangkat ke Mesir. Selama ia berada di Mekkah ataupun Madinah tidak 


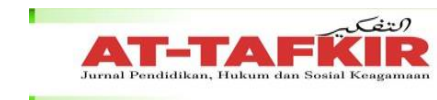

VOLUME 13 NOMOR 2 TAHUN 2020

P-ISSN : 1979-9357

E-ISSN : 2620-5858

sempat mengambil ijazah dalam thariqat apapun karena keterbatasan waktu lamanya. Hal ini didorong oleh dua kondisi:

I. Karena beliau berada di tanah suci lebih kurang hanya tiga bulan, waktu yang sangat singkat bagi beliau yang mempunyai cita-cita besar untuk menggali ilmu dari berbagai ulama. Sehingga tidak tersisa waktu beliau untuk menemui dan berdiskusi dengan para ulama lainnya.

II. Pada umumnya para pelajar yang datang ke tanah suci untuk mengamalkan thariqat, mengambil ijazah, dan berkhalwat harus berada di tanah suci pada bulan Ramadhan. Karena pada bulan Ramadhan halaqah pengajian sepi bahkan libur. Semua waktu dalam bulan Ramadhan difokus untuk beribadah. Sementara Abuya Muhammad Wali berada di tanah suci bukan pada bulan Ramadhan.

f) Pengembangan keilmuan dalam bidang tasawuf

Kepulangan Abuya Muhammad Wali dari tanah suci beliau mendapat sambutan dari murid-muridnya serta dari ulama-ulama Minangkabau lainnya seperti Syekh Ali Khatib, Syekh Sulaiman Ar-Rasuli, Buya Syekh Jamil Jaho. Hal ini dikarenakan dengan kembalinya Abuya Muhammad Wali akan semakin bertambah kokoh dan kuatnya benteng Ahlussunnah wal jamaah di padang khususnya. Dikalangan ulama-ulama besar itu Abuya Muhammad Wali merupakan tergolong usia yang termuda di antara mereka, sehingga dalam perdebatan perdebatan ilmu keagamaan yang populer pada masa itu, Syekh Abuya Muhammad Wali lebih didahulukan oleh ulama dari kelompok kaum tua lainnya untuk menghadapi ulama dari kaum muda. Uniknya kedua belah pihak (Ulama kaum Tua dan Ulama kaum Muda) menampilkan orang-orang muda dari kedua belah pihak. Sehingga antara ulama tua dari kedua belah pihak seolah-olah tidak terjadi perbedaan pendapat.

Walaupun demikian Abuya Muhammad Wali telah memiliki ilmu pengetahuan agama yang luas, namun ada hal yang belum memuaskan hati beliau yaitu ilmu yang beliau miliki belum mampu menenangkan batin beliau, akhirnya beliau memutuskan untuk memasuki jalan tasawuf sebagaimana yang telan ditempuh oleh ulama-ulama sebelumnya. Seperti ar-Raniri di Aceh mengembangkan thariqat Rifa iyah dan Syekh Abdur Rauf yang lebih dikenal oleh masyarakat Aceh dengan sebutan Teungku Syiah Kuala mengembangkan thariqat Syattariyah, Abuya Muhammad Wali memilih dan mengembangkan Thariqat Naqsyabandiyah, sebuah thariqat yang popular di Sumatera Barat dikala itu.

Beliau berguru kepada seorang ulama besar yang mengembangkan Thariqat di Sumatera Barat kala itu yaitu Syekh Abdul Ghaniy Al Kamfary bertempat di Batu Bersurat, Kampar, Bangkinang. Ia melaksanakan rutinitas "suluk" selama 40 hari. Menurut sebahagian sejarah menyebutkan bahwa selama dalam khalwat-nya dengan riyadhah dan munajat berupa mengamalkan zikir-zikir sebagaimana atas petunjuk Syekh Abdul Ghani beliau sempat mengalami lumpuh sehingga tidak bisa berjalan untuk mandi dan berwudhu. Setelah selesai berkhalwat beliau merasakan kelegaan batin yang luar biasa jauh melebihi kebahagiannya ketika mendapat ilmu

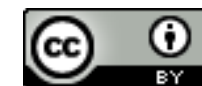

This work is licensed under a Creative Commons Attribution 4.0 International License 


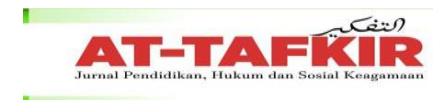

VOLUME 13 NOMOR 2 TAHUN 2020

P-ISSN : 1979-9357

E-ISSN : 2620-5858

yang bersifat lahiriyah selama ini. Beliau mendapat ijazah mursyid dari Syekh Abdul Ghani sebagai pertanda bahwa beliau sudah diperbolehkan untuk mengembangkan thariqat Naqsyabandiyah yang beliau terima.

Setelah mendapat ijazah thariqat beliau kembali ke Kota Padang dan mendirikan sebuah Pesantren yang bernama Bustanul Muhaqqiqin di Lubuk Begalung, Padang. Sebuah pesantren yang terdiri dari beberapa surau dan asrama. banyak murid yang mengambil ilmu di pesantren tersebut bahkan juga santri santri dari Aceh. Tetapi pada saat Jepang masuk ke Padang, Abuya Muhammad Wali mengambil keputusan pulang ke Aceh karena di Aceh beliau merasa lebih tenang dan nyaman dalam mengamalkan dan mengembangkan ilmu yang telah ia miliki. Di antara guru yang pernah ia belajar dan menimba ilmu darinya, antara lain (Abbas):

1. Syeikh H.M. Salim Aceh Selatan, ayahnya sendiri.

2. Syeikh M. Idris Aceh Selatan.

3. Syeikh M. 'Ali Lampisang, Aceh Besar.

4. Syeikh Mahmud Blang Pidie.

5. Syeikh H. Hasan Kureng Kale, Aceh Besar.

6. Syeikh Hasbullah Indrapuri, Aceh Besar.

7. Syeikh Abdul Ghani Al-Khalidi Batu Basurek, Bangkinang Sumbar.

\section{Karya Intelektual}

Adapun karya tulih yang berhasil dibukukan oleh Abuya Muhammad Wali dalam berbagai disiplin ilmu agama adalah:

a. Al fatwa. Ini merupakan sebuah kitab dengan redaksi bahasa Indonesia dengan tulisan Arab (Arab-Jawi), berisi kumpulan fatwa-fatwa Abuya Muhammad Wali mengenai berbagai macam permasalahan agama yang muncul dalam masyarakat. Fatwa-fatwa ini dihimpun oleh muridnya Tgk. Basyah Lhong Aceh Besar.

b. Tanwirul Anwar. Kitab ini berisi penjelasan dan uraian mengenai masalah masalah aqidah dan ketauhidan. Dalam materinya, kitab ini lebih menekankan kepada pembelajaran tauhid bagi orang yang sudah mahir (bukan orang awam), sehingga kitab ini tidak dianjurkan untuk dipelajari bagi orang awam.

c. Risalah adab zikir ismuz Zat. Kitab ini memuat tentang tata cara melakukan ibadah zikir khusus yang terdiri dari kalimat Laila ha Illlah, Allah, dan lain-lain.

d. Permata Intan, sebuah risalah singkat berbentuk soal-jawab mengenai masalah i tiqad

e. Hasyiah Tuhfah al-Muhtaj, berisi masalah-masalah fiqh. Abuya memberikan komentarnya terhadap bacaan kitab Tuhfah ketika ia mengajar kitab ini kepada santri senior.

f. Intan Permata, risalah singkat berisi masalah tauhid.

\section{Kondisi Sosial Politik}

Bidang sosial kemasyarakatan, Abuya Muhammad Wali merupakan sosok yang sangat tawadhu', peramah, baik hati, pemurah, dan berani menegakkan 


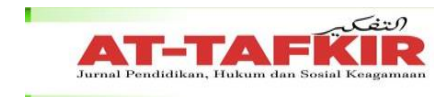

VOLUME 13 NOMOR 2 TAHUN 2020

P-ISSN : 1979-9357

E-ISSN : 2620-5858

kebenaran. Setiap istri, anak, murid, teman, sahabat, di berbagai golongan dan tempat merasa serta menganggap bahwa Abuya Muhammad Wali lebih sayang kepadanya dari pada yang lain, dan melupakan kelebihan padanya sehingga orang lain merasa senang dan tertarik padanya (Waly M. , 1993).

\section{Telaah Anatomi Kitab Al-Fatawi}

Kitab ini dengan metode sajiannya diawali dengan tanya jawab dilengkapi dengan dalil yang bersumber dari berbagai literatur yang ada, namun lebih dominan literatur yang digunakan adalah kitabnya para ulama Syafii'ah, kitab membicarakan tentang permasalahan yang berkembang di dalam masyarakat baik masayarakat Aceh maupun di luar Aceh. Kitab ini berisi jawaban-jawaban Abuya Muhammad Wali yang kemudian dikumpulkan dan dihimpun oleh kātib (sekretaris beliau) yaitu teungku. Basyah Lhoong. Kitab ini selesai ditulis pada tanggal 02 Dzulhijjah $1379 \mathrm{H}$ atau bertepatan dengan 28 April 1960 M. Penulisan kitabnya dengan mengunakan tulisan Arab Jawi, yang kemudian direvisi dengan tulisan bahasa Indonesia oleh teungku Habibie Wali yang terbit oleh Taufiqiyah Sa'adah Banda Aceh (Waly A. M.).

Kitab ini tidak hanya mengutip beberapa jawaban hukum dengan semata atas pengetahuan beliau sendiri namun juga memberikan dasar-dasar dalilnya (referensi), baik dari keterangan alquran, hadis ataupun Ijmak dari para ulama, dan juga penukilan dasar dalil dari beberapa pendapat ulama tersebut juga Abuya sebutkan di dalamnya. Abuya Muhammad Wali juga memberikan beberapa jawaban hukum dengan hasil ijtihadnya, sebagaimana yang sudah disebutkan sebelumnya. Tidak hanya semata akal atau hasil dari analisa beliau yang menjadi tambahan terhadap jawaban didalam kitabnya, namun beliau juga mengunakan ilmu lainnya sebagai sumber data pendukung dalam memberikan terhadap jawaban hukum tersebut seperti, ilmu mantiq (ilmu logika), ilmu balaghah (ilmu tata bahasa) dan ilmu furuiyyah lainnya (yaitu ilmu cabang lainnya), tentunya sandaran ilmu semacam ini adalah penguat bagi setiap dalil yang beliau tujukan, sehingga tidak semata bersumber kepada nash Alquran dan hadis namun beliau merujuk kepada sumber yang lain sebagai pendukung terhadap pesan-pesan yang disampaikan oleh kedua nash tersebut. Semua permasalahan masyarakat ditulis dan dibukukan, selain yang tersebut di atas, masih sangat banyak jawaban hukum/ fatwa Abuya Muhammad Wali yang belum dikumpulkan dalam bentuk tulisan atau buku, tapi tersimpan di dalam memori para santri dan masyarakat lainnya. Dari uraian di atas, dapat dianalisa bahwa permasalahan yang dijawab oleh Abuya tidak hanya pada satu bahagian masalah saja, namun terdiri dari beragam persoalan dan muncul dalam masyarakat baik itu bidang ketauhidan, tasawuf, fikih, dan bidang-bidang lainnya.

\section{PEMBAHASAN}

Abuya Muhammad Waly al-Khalidi adalah mujaddid (pembaharu) pada abad ke-14 hijrah, dan seorang ulama sangat produktif, semasa hidup beliau disibukkan dengan kegiatan keilmuan, banyak karangan yang beliau buat, yang menunjukkan keluasan ilmu yang beliau miliki. Salah satu karya beliau di bidang 
VOLUME 13 NOMOR 2 TAHUN 2020

P-ISSN : 1979-9357

E-ISSN : 2620-5858

adalah kitab al-Fatawa yang merupakan kumpulan jawaban dari pertanyaanpertanyaan yang dikirimkan oleh masyarakat dari berbagai daerah di Aceh maupun luar Aceh. Kitab al-fatawa memiliki kontribusi yang besar dalam dinamika perkembangan hukum Islam di wilayah Kepulauan Nusantara ini. Kitab itu dibutuhkan bagi setiap lapisan masyarakat, baik ulama dalam menyusun kitab karangannya, pemerintah dalam membuat regulasi peraturan perundanganundangan, maupun kalangan dunia pesantren dalam kurikulum pelajarannnya. Pendapat-pendapat yang tertuang dalam kitab tersebut merupakan pemikiran fiqh klasik, tentunya membutuhkan sentuhan transformatif kekinian.

\section{DAFTAR PUSTAKA}

Abbas, S. (n.d.). Keagungan Mazhab Syafi'i. Jakarta: Pustaka Tarbiyah.

Fikri, M. (n.d.). Transformasi Tradisi Akademik Islam dan Kontribusinya Terhadap

Resolusi Konflik Agama di Aceh. IRICIS I. Banda Aceh: Univeristas Islam Negeri Ar-Raniry.

Waly, A. (2006). Oto Biografi (Sejarah Hidup) Abuya Syeikh Haji Muhammad Waly al-Khalidy. Aceh Selatan: Darul Ihsan.

Waly, A. M. (n.d.). al-Fatawa. Banda Aceh: Taufiqiyah Sa'adah.

Waly, M. (1993). Ayah Kami Maulana Syeikh Haji Muhammad Waly al-Khalidy

(Teungku Syeikh Haji Muda Wali). In Kulliyah Of Laws International Islamic University. Malaysia.

Zuhri, S. (2014). Dayah Menapaki Jejak Pendidikan Warisan Endatu Aceh. Banda Aceh: Ulee Sagoe Press. 